\title{
Changes in the surface ozone after the windstorm in 2004, in the High Tatras
}

\author{
Svetlana Bičárová $₫$, Dušan Bilčík ${ }^{1}$, Pavol Nejedlik $k^{1}$, Rastislav Janík ${ }^{2}$, Daniela Kellerová ${ }^{2}$ \\ ${ }^{1}$ Earth Science Institute of the Slovak Academy of Sciences, Dúbravská cesta 9, 84528 Bratislava, Slovak Republic, \\ e-mail: bicarova@ta3.sk \\ ${ }^{2}$ Institute of Forest Ecology of the Slovak Academy of Sciences, Ludovíta Štúra 2, 96053 Zvolen, Slovak Republic
}

\section{Abstract}

Extreme wind event in November 2004 caused spacious destruction of slope forests in the Tatra National Park, Slovakia. Relevant changes of land cover motivated researchers to investigate damaged forest ecosystem and its response to different environmental conditions. Surface ozone $\left(\mathrm{O}_{3}\right)$ is a minor but not negligible compound of the ambient air. Control strategies for the reduction of $\mathrm{O}_{3}$ precursor emissions have been applied in Europe during the last two decades. In spite of these reductions, air quality indices for $\mathrm{O}_{3}$ suggest that highland sites are more vulnerable to health and environmental risk than lowlands where mostly emissions from road transport and industry are produced. Both anthropogenic sources and biogenic precursors (BVOC) from forest vegetation play a relevant role in the tropospheric photochemistry, especially at mountainous and rural locations. The parameters of air quality are measured at background station Stará Lesná in the High Tatras region since 1992 in frame of an European project EMEP. Long-term data series (1992-2013) of $\mathrm{O}_{3}$ concentrations obtained for site Stará Lesná provide specific opportunity to investigate the response of BVOC reduction on $\mathrm{O}_{3}$ variability after windstorm 2004. Evaluation of these data indicates moderate increase of annual, monthly and hourly $\mathrm{O}_{3}$ means for the period from 2005 to 2013 in comparison with the previous period 1992-2004. Temporal interpolation shows evident changes of $\mathrm{O}_{3}$ concentrations, especially $\sim 30 \%$ increase for night hours in spring season and on the contrary $\sim 15 \%$ decrease for daylight afternoon hours in summer season. Statistically significant changes were identified for spring months (April and May, 0-6 hours) and summer months (July, 12-20 hours). Increasing $\mathrm{O}_{3}$ values in the night may be associated with the absence of BVOC for ozonolysis reaction that is one of the mechanism for $\mathrm{O}_{3}$ depletion. On the other hand, the decline of daylight $\mathrm{O}_{3}$ values in summer suggests lower $\mathrm{O}_{3}$ production via photochemical mechanism.

\section{KeY WORDS}

ozone air pollution, EMEP site, extreme windstorm event, forest vegetation, BVOC, High Tatra Mts., Western Carpathians 


\section{DE GRUYTER

\section{INTRODUCTION}

Although surface ozone $\left(\mathrm{O}_{3}\right)$ is a minor component of ambient air, it also represents a key marker of secondary air pollution. Secondary pollutants are formed in the troposphere due to the transformation of primary emissions from variety of anthropogenic and natural sources. Tropospheric $\mathrm{O}_{3}$ is produced by the photochemical oxidation of primary emissions including carbon monoxide $(\mathrm{CO})$, methane $\left(\mathrm{CH}_{4}\right)$ and nonmethane hydrocarbons (NM volatile organic compounds) in the presence of nitrogen oxides $\left(\mathrm{NO}_{\mathrm{x}}\right)$. Globally, the projection of air quality (Stocker et al. 2013) estimates reduction of $\mathrm{O}_{3}$ background associated with climate change. However, expected high $\mathrm{CH}_{4}$ levels can offset this decrease, raising $\mathrm{O}_{3}$ background by year 2100 on average by about 8 ppb $(25 \%$ of current levels) relative to scenarios with small $\mathrm{CH}_{4}$ changes. Airborne pollutants, such as $\mathrm{O}_{3}, \mathrm{CO}$, $\mathrm{NO}_{\mathrm{x}}$ and aerosols (solid or liquid particulate matter), contribute to the deterioration of air quality. Exposure to such pollutants exacerbates respiratory and cardiovascular diseases, harms plants and damages buildings. There is strong evidence that tropospheric $\mathrm{O}_{3}$ has also a detrimental impact on vegetation physiology, and therefore on its $\mathrm{CO}_{2}$ uptake. This reduced uptake leads to an indirect increase in the atmospheric $\mathrm{CO}_{2}$ concentration.

Complex chemistry, dynamical meteorological conditions and climatic variability significantly affect unstable balance between $\mathrm{O}_{3}$ production and decomposition. Relevant decrease of emissions from road transport sector has been achieved in Europe during last decades; however, the occurrence of extraordinary $\mathrm{O}_{3}$ events during extreme heat waves indicates vulnerability to air pollution health effects (Fiala 2003). In addition, the long-range transport of polluted air masses suggests larger $\mathrm{O}_{3}$ burden for highlands than for lowlands through a larger part of the emissions from transport and industry is produced in the lowlands. Longterm $\mathrm{O}_{3}$ exposure that exceeds air quality indices such as $\mathrm{SOMO}_{35}$ or $\mathrm{AOT}_{40}$ may pose health and environmental risks, especially for highland regions in Europe (Bičárová et al. 2013).

Science Policy Report (Fowler et al. 2008) focused on the issue of ozone air pollution in the $21^{\text {st }}$ century includes several recommendations. One of them is to establish long-term field studies for the assessment of the combined effects of $\mathrm{O}_{3}$, elevated $\mathrm{CO}_{2}$, climate change and other environmental stressors both on species of economic importance and on a range of natural and seminatural ecosystems to improve the evidence base of $\mathrm{O}_{3}$ effects on plant productivity, important crop and forest species and biodiversity.

Cooperative Programme for Monitoring and Evaluation of the Long-range Transmission of Air Pollutants (EMEP project) represents European base for international cooperation in possible solving of transboundary air pollution problems. After Slovak Republic became a part of EMEP, $\mathrm{O}_{3}$ monitoring station at Stará Lesná was included to the EMEP monitoring network (1991). Ozone data obtained at EMEP monitoring station Stará Lesná during the period from 1992 to 2013 represent the longest time series of $\mathrm{O}_{3}$ measurements in Slovakia.

In November 2004, extraordinary windstorm caused considerable damages in the region of High Tatras. The windstorm strongly damaged almost one third of forested area - approximately 12600 ha from total 46000 ha of forest vegetation of the Tatra National Park (Fleischer, 2011). Forest vegetation is an important natural source of Biogenic Volatile Organic Compounds (BVOC) such as isoprene and monoterpenes that play a significant role in the tropospheric photochemistry, especially in suburban and rural locations (Chameides et al. 1992).

The aim of this paper is to evaluate the variability of $\mathrm{O}_{3}$ concentrations at EMEP station Stará Lesná for the period 1992-2013 and to investigate $\mathrm{O}_{3}$ changes in association with the decreasing amount of local BVOC precursors from forest vegetation after windstorm in 2004.

\section{Material AND Methods}

\section{EMEP monitoring station Stará Lesná}

EMEP air quality monitoring station at Stará Lesná is situated at the foothills of the High Tatra Mts. $\left(49^{\circ} 09^{\prime} \mathrm{N}, 20^{\circ} 17^{\prime} \mathrm{E}, 810 \mathrm{~m}\right.$ a.s.1.), near the Slovak-Polish border (fig. 1). It is the background area without industrial sources surrounded mostly by forests and pastures. From the northwestern site it is enclosed by main mountain ridge with dominant peak of Lomnický štít (2635 $\mathrm{m}$ a.s.l.) and Skalnatá dolina valley. At the southeastern site it is opened to the Popradská kotlina basin. 

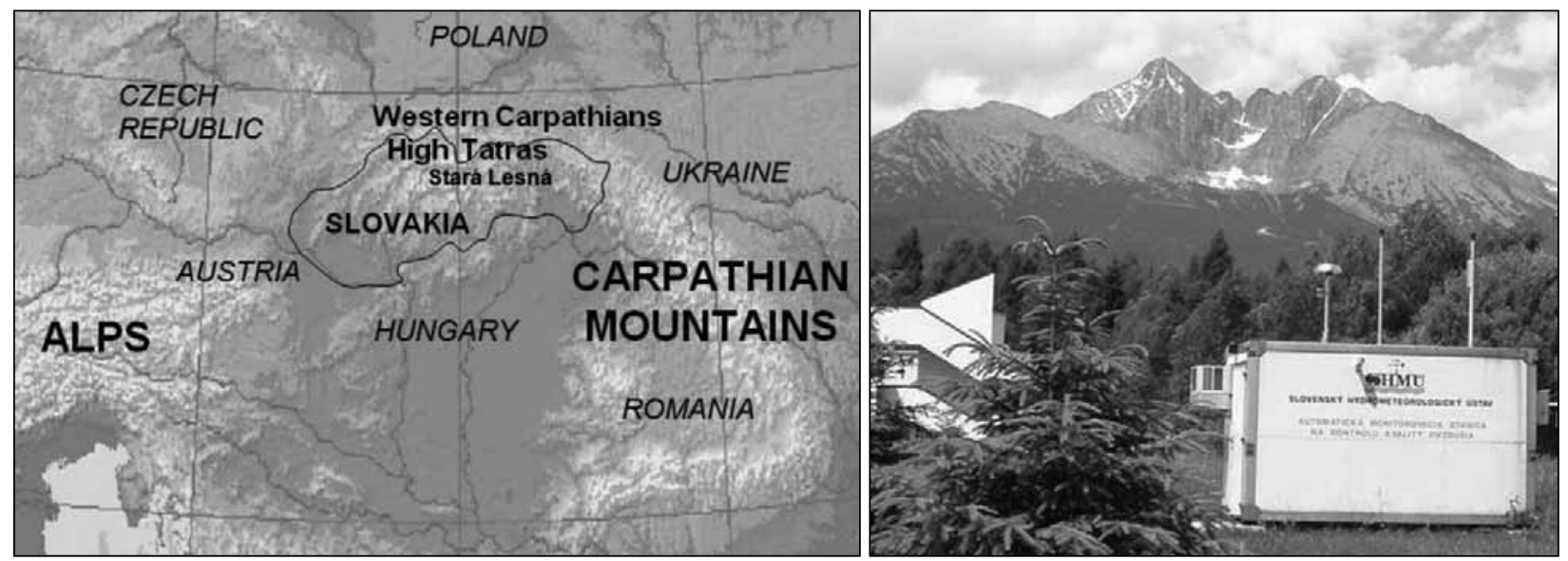

Figure 1. Position of EMEP air quality monitoring station at background site Stará Lesná

Stará Lesná station is positioned at the lower border of mountain forest belt. Forest is dominant vegetation type in the lower (supramontane) part of Skalnatá dolina (up to $1500 \mathrm{~m}$ a.s.l) and according to forest altitudinal classification it is a part of the Norway spruce vegetation zone. Norway spruce (Picea abies (L.) Karst.) is an absolutely dominant tree species. Further to that European larch (Larix decidua Mill.), which can be found either on extremely rocky sites or, conversely, on deep loamy soils which are often affected by windstorms (Škvarenina and Fleischer 2013), occupies a certain percentage of the respective area.

The measurement of $\mathrm{O}_{3}$ concentration is done by Slovak Hydrometeorological Institute (SHMI) that is national participating institute in EMEP project. Continuously operating air monitoring station at Stará Lesná (fig. 1) measures $\mathrm{O}_{3}$ concentration by analyser Horiba APOA360. Hourly means of $\mathrm{O}_{3}$ are registered in EMEP database under code SK04 (www.emep.int). Automatic $\mathrm{O}_{3}$ analyser is regularly calibrated and data are validated in data centre of SHMI. Meteorological observations have been carried out at experimental workplace of the Geophysical Institute of the Slovak Academy of Sciences (GPI SAS) at Stará Lesná since 1988. Evaluation of meteorological measurements for the period 1988-2013 indicates that the climate of this location is moderately cool with average annual air temperature $5.9^{\circ} \mathrm{C}$ that seasonally varies from $-3.5^{\circ} \mathrm{C}$ (DJF) to $15.2^{\circ} \mathrm{C}$ (JJA). Extreme air temperatures range between -26.5 and $34.2^{\circ} \mathrm{C}$. Growing season length is about 195 days. Mean annual sum of precipitation is
$744 \mathrm{~mm}$ and seasonal comparison shows nearly two times more precipitation totals in summer than in winter season. Snow depth is on average $35 \mathrm{~cm}$, extraordinary over $50 \mathrm{~cm}$. Annual mean of relative air humidity reaches about $78 \%$. Wet periods last from 5 to 13 consecutive wet days; substantially longer are dry periods which last usually from 14 to 39 days. Mean annual sum of sunshine duration is 1806 hours per year and number of sunny days is clearly lower than number of cloudy days. Mean surface air pressure $920.4 \mathrm{hPa}$ relates to altitudinal position of the site. Wind blows mostly from the more open southern side. Despite relatively low annual mean of wind speed $\left(2.1 \mathrm{~m} \mathrm{~s}^{-1}\right)$ the occurrence of strong wind gusts above $40 \mathrm{~m} / \mathrm{s}$ which can cause spatial destruction of natural environment such as in November 2004 is do occur.

\section{Windstorm in the High Tatras in 2004}

Standard wind measurements at meteorological observatory Stará Lesná (2000-2013) show that prevailing winds blow predominantly from SSW (South-Southwest) direction on the lower southern slopes in the High Tatras. Mean hourly wind speeds fluctuated around $2.1 \mathrm{~m} \mathrm{~s}^{-1}$. Nearly $80 \%$ of wind speed data ranged between 0 and $4 \mathrm{~m} \mathrm{~s}^{-1}$. Wind speeds of $4 \mathrm{~m} \mathrm{~s}^{-1}$ occurred particularly in spring months (March, April, May) and then in November between 10 and 16 hours CET. Extraordinary gust $45.2 \mathrm{~m} \mathrm{~s}^{-1}\left(163 \mathrm{~km} \mathrm{~h}^{-1}\right)$ observed during windstorm in November 2004 was not overcome during next years. A wind destructive potential related to gusty winds $>40 \mathrm{~m} \mathrm{~s}^{-1}\left(144 \mathrm{~km} \mathrm{~h}^{-1}\right)$ arises from specific syn- 


\section{DE GRUYTER \\ OPEN}

74
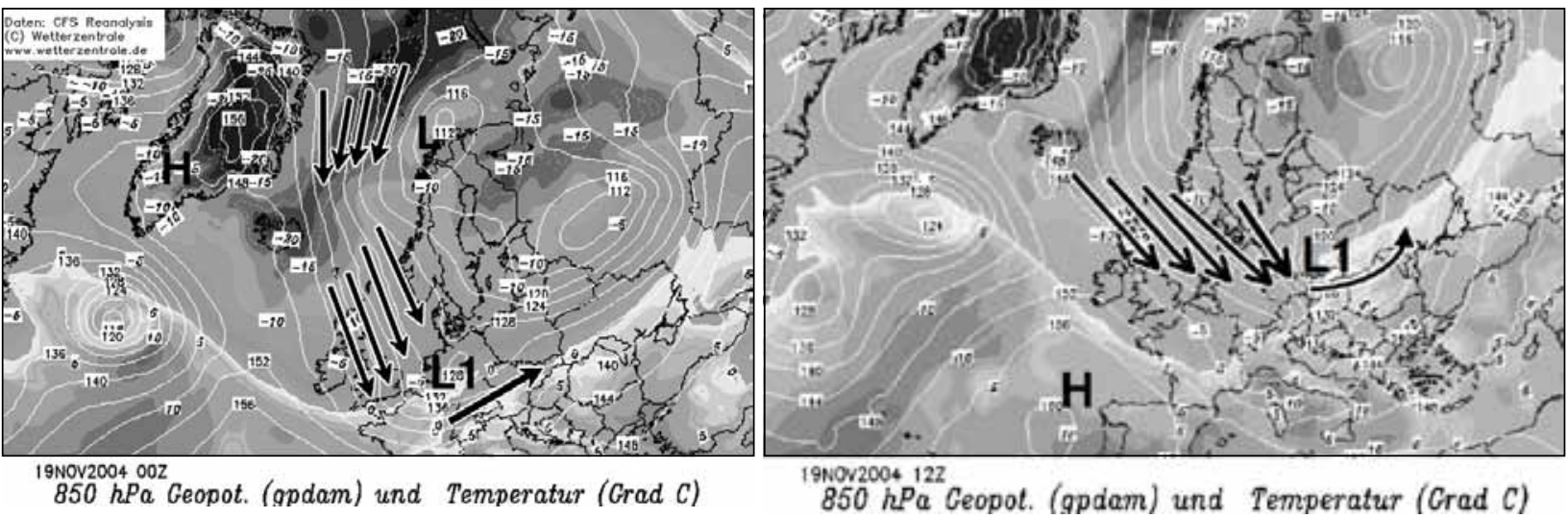

Figure 2. Synoptic situation over Europe on $19^{\text {th }}$ Nov 2004 (http://www.wetterzentrale.de)
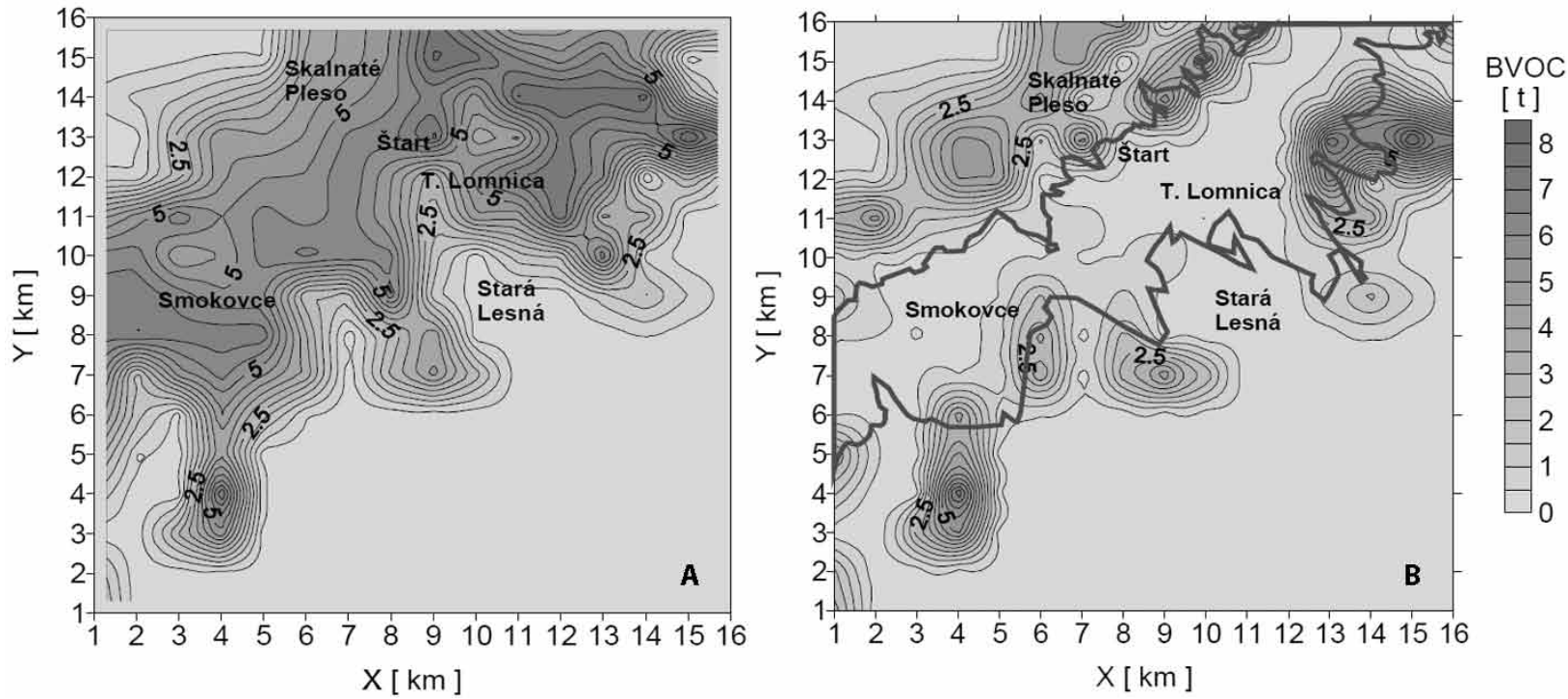

Figure 3. Spatial distribution of total BVOC emissions (isoprene, total monoterpenes and other VOC) for the High Tatras model domain of periods: A - before windstorm, B - after windstorm (solid grey line - border of damaged forest area)

optic situation associated with unusual distribution and power of different air pressure fields over Europe. Special location of different air pressure masses between Greenland (high pressure-H) and Northern Scandinavia (low pressure-L) with strong force of air pressure gradient brought intensive flows of cold air from the north to the western part of Europe at midnight (fig. 2, left). Alongside above mentioned another low-pressure area (L1) began to form over West Germany. During the day L1 moved to east and eye of cyclone (fig. 2, right) intensified northwestern airflows over the Tatras in the afternoon. Deep decrease of air pressure to the value of $890 \mathrm{hPa}$ and frequent gusts $>40 \mathrm{~m} \mathrm{~s}^{-1}\left(144 \mathrm{~km} \mathrm{~h}^{-1}\right)$ were recorded at meteorological station Stará Lesná between 15 and 18 hours of CET. Enormous power of this wind caused damage of large forested area on the lower southern slope of the High Tatras.

\section{Changes of BVOC after forest destruction in 2004}

The measurement and modelling of BVOC are essential for understanding regional and global atmospheric chemistry, carbon cycles and climate. Emissions modelling systems (GLOBEIS, ENVIRON) and other global models of tropospheric chemistry (GEOS-CHEM) incorporate the algorithm developed by Guenther et 
al. (1993). Emission rates are a function of land cover and environmental conditions which are characterised from user-supplied data using the most updated emissions algorithms (Guenther et al. 1999a,b). Estimations of BVOC emissions for the High Tatras region before and after devastative windstorm using BEIS2 series of GLOBEIS model show decrease of BVOC emissions in the range $53-59 \%$ that is adequate to $59 \%$ reduction of forest vegetation area (Bičárová and Fleischer 2006).

Land cover of model domain $(16 \mathrm{~km} \times 16 \mathrm{~km}$, $1 \mathrm{~km}$ grid) involved forest stands with prevailing tree species: Norway spruce - Picea abies (L.) Karst., European Alder - Alnus glutinosa (L.) Gaertn., European Larch - Larix decidua Mill., Scots pine - Pinus sylvestris L., Silver fir - Abies alba Mill and other vegetation. The forest vegetation covered $102 \mathrm{~km}^{2}$ (40\%) before and $42 \mathrm{~km}^{2}(16.4 \%)$ after windstorm. Differences of total emissions of native species isoprene (ISO), total monoterpenes (TMT), other $\mathrm{VOC}_{\mathrm{s}}(\mathrm{OVC})$ reflected land use and vegetation structure changes due to windstorm disturbance. Estimates of total quantity BVOC for the considered periods from July to September in 2004 and 2005 were $606 \mathrm{t}$ and $275 \mathrm{t}$, respectively. Dominant component of BVOC is a group of monoterpenes $(\sim 40 \%)$.

\section{Results AND DISCUSSION}

\section{Variability of $\mathrm{O}_{3}$ concentration at Stará Lesná for period 1992-2013}

\section{Mean annual $\mathrm{O}_{3}$ values}

Multiple variable analysis of validated $\mathrm{O}_{3}$ data (tab. 1) shows that mean annual values fluctuate around longterm $\mathrm{O}_{3}$ mean of $64.1 \pm 3.6 \mu \mathrm{g} \mathrm{m}^{-3}$ (fig. 4). This value is consistent with results for other EMEP station situated at highlands sites below of $1000 \mathrm{~m}$ a.s.l. (Bičárová et al. 2013). Changes of annual means during period 1992-2013 are statistically not significant. However, mean values for period before (1992-2004) and after windstorm (2005-2013) increased from 62.5 to $67.6 \mu \mathrm{g} \mathrm{m}^{-3}$. Coefficients of variation document higher variability $(22 \%)$ of annual means for the period 1992-2004 than for period 2005-2013 (5\%). It corresponds with wider range of mean values $\left(50-72 \mu \mathrm{g} \mathrm{m}^{-3}\right)$ before 2005 than in following years. Only mean values above $60 \mu \mathrm{g} \mathrm{m}^{-3}$ started occur since 2005 .
Table 1. Summary statistics of $\mathrm{O}_{3}$ time series data, Stará Lesná (1992-2013)

\begin{tabular}{|c|c|c|c|}
\hline Year/Period & $\begin{array}{c}\text { Average } \\
\mathrm{O}_{3}\left[\mu \mathrm{g} \mathrm{m}^{-3}\right]\end{array}$ & $\begin{array}{l}\text { Standard } \\
\text { deviation }\end{array}$ & $\begin{array}{c}\text { Coeff. of } \\
\text { variation } \%\end{array}$ \\
\hline 1992 & 65.3 & 17.5 & $27.0 \%$ \\
\hline 1993 & 63.6 & 11.3 & $18.0 \%$ \\
\hline 1994 & 64.3 & 13.6 & $21.0 \%$ \\
\hline 1995 & 69.6 & 14.9 & $21.0 \%$ \\
\hline 1996 & 71.8 & 26.6 & $37.0 \%$ \\
\hline 1997 & 50.6 & 13.1 & $26.0 \%$ \\
\hline 1998 & 50.8 & 13.6 & $27.0 \%$ \\
\hline 1999 & 66.0 & 20.1 & $30.0 \%$ \\
\hline 2000 & 60.1 & 14.7 & $25.0 \%$ \\
\hline 2001 & 55.3 & 22.1 & $40.0 \%$ \\
\hline 2002 & 55.6 & 13.7 & $25.0 \%$ \\
\hline 2003 & 66.6 & 15.3 & $23.0 \%$ \\
\hline 2004 & 61.7 & 13.8 & $22.0 \%$ \\
\hline 1992-2004 & 62.5 & 7.5 & $22.0 \%$ \\
\hline 2005 & 70.4 & 15.7 & $22.0 \%$ \\
\hline 2006 & 70.6 & 20.0 & $28.0 \%$ \\
\hline 2007 & 68.0 & 16.4 & $24.0 \%$ \\
\hline 2008 & 70.3 & 14.8 & $21.0 \%$ \\
\hline 2009 & 61.5 & 16.7 & $27.0 \%$ \\
\hline 2010 & 67.6 & 12.0 & $18.0 \%$ \\
\hline 2011 & 65.3 & 15.4 & $24.0 \%$ \\
\hline 2012 & 63.3 & 12.4 & $20.0 \%$ \\
\hline 2013 & 71.1 & 13.1 & $18.0 \%$ \\
\hline $2005-2013$ & 67.6 & 3.5 & $5 \%$ \\
\hline 1992-2013 & 64.1 & 3.6 & $10 \%$ \\
\hline
\end{tabular}

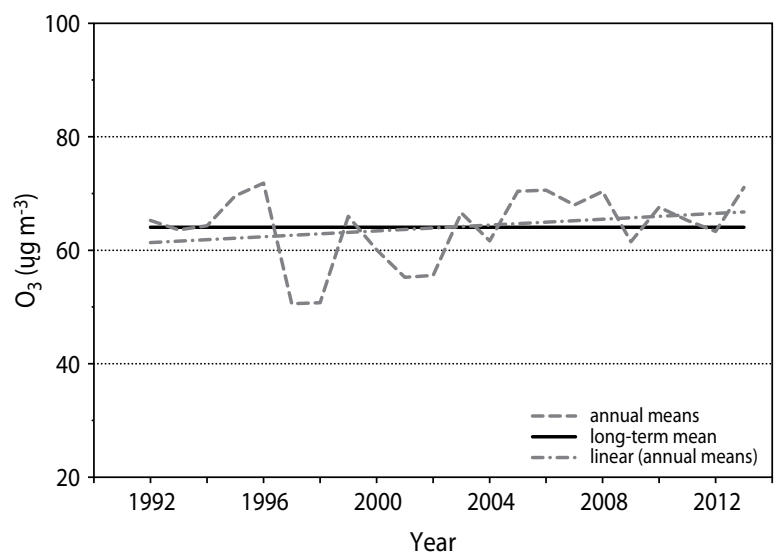

Figure 4. Annual means and long-term $\mathrm{O}_{3}$ mean $\left[\mu \mathrm{g} \mathrm{m}^{-3}\right]$ at Stará Lesná for period 1992-2013 


\section{DE GRUYTER OPEN}

\section{Maxima - hourly, daily and monthly $\mathrm{O}_{3}$ concentrations}

The EU has defined an Alert threshold of $240 \mu \mathrm{g} \mathrm{m}^{-3}$. It represents a level of brief exposure beyond which there is a general risk to human health. Particularly sensitive groups of the population can be hurt already at the level $180 \mu \mathrm{g} \mathrm{m}^{-3}$. The level of $180 \mu \mathrm{g} \mathrm{m}^{-3}$ is called Information threshold. National authorities are required to inform the public and give advice when the thresholds are reached. Maximal $\mathrm{O}_{3}$ concentrations recorded at Stará Lesná are shown in figure 5.

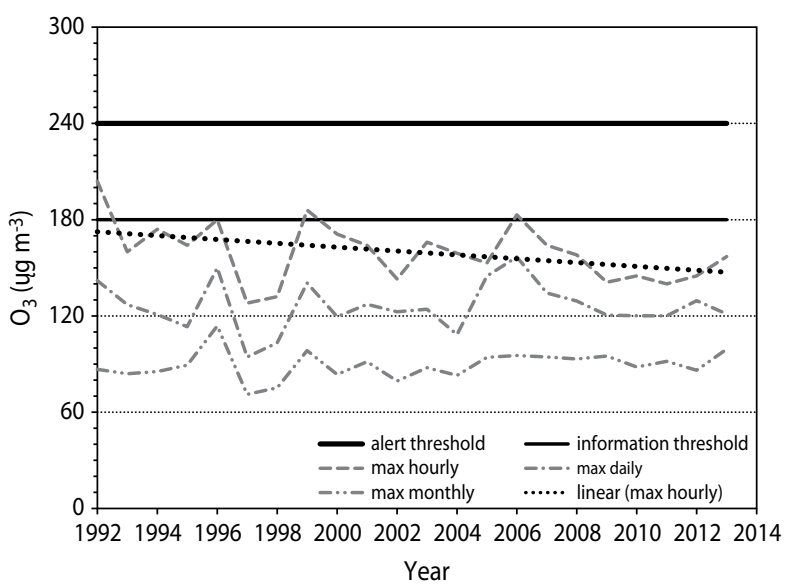

Figure 5. Maximal $\mathrm{O}_{3}$ concentrations $\left[\mu \mathrm{g} \mathrm{m}^{-3}\right]$ : hourly, daily and monthly values at Stará Lesná for the period 1992-2013 with respect to the respective thresholds

Hourly maxima were frequently close to the information threshold of $180 \mu \mathrm{g} \mathrm{m}^{-3}$. They exceeded it altogether nine times. Seven of such situations happened in 1992 and once in 1999 and 2006 each. The alert threshold $240 \mu \mathrm{g} \mathrm{m}^{-3}$ was not overstepped during the whole considered period. The highest mean hourly $\mathrm{O}_{3}$ concentration ever recorded $\left(204 \mu \mathrm{g} \mathrm{m}^{-3}\right)$ occurred in the afternoon in July 1992. Maxima of daily mean $\mathrm{O}_{3}$ concentration ranged from 94 to $157 \mu \mathrm{g} \mathrm{m}^{-3}$ and maxima of monthly means varied from 71 to $114 \mu \mathrm{g} \mathrm{m}^{-3}$. Concerning hourly maxima substantially higher values $\sim 300 \mu \mathrm{g} \mathrm{m}^{-3}$ occurred at Slovak urban stations during the heat wave 2003 due to enormous $\mathrm{O}_{3}$ production and weak dispersion conditions. However, daily $\mathrm{O}_{3}$ concentration at rural stations was higher than at urban stations in Slovakia during this heat wave event (Bičárová et al. 2004). In urban areas, daily $\mathrm{O}_{3}$ concentrations may be lower than the rural ones due to chemical feeding by local NO. In the suburbs and further downwind of large cities where local $\mathrm{NO}_{\mathrm{x}}$ emissions are lower the formation generally dominates over depletion and elevated $\mathrm{O}_{3}$ levels are found as a consequence of this process (Louka et al. 2003).

\section{Seasonal $\mathrm{O}_{3}$ changes}

The course of monthly $\mathrm{O}_{3}$ means at Stará Lesná (fig. 6) shows primary maximum in spring $\left(88 \mu \mathrm{g} \mathrm{m}^{-3}\right.$ in April) and secondary one in summer (69 $\mu \mathrm{g} \mathrm{m}^{-3}$ in August). The primary maximum is associated with convenient photochemical conditions (positive changes in sunshine duration and UV radiation, increase of air temperature, decrease of relative humidity) and the abundance of $\mathrm{O}_{3}$ precursors $\left(\mathrm{NO}_{2}\right.$ and $\left.\mathrm{NO}_{3}\right)$ accumulated in winter aerosols (Bičárová and Fleischer 2004). Summer maxima appear to be related to special $\mathrm{O}_{3}$ production influenced by the transport of abundant $\mathrm{O}_{3}$ precursors over $\mathrm{Eu}-$ rope in unusual warm weather situation (Bičárová et al. 2005).

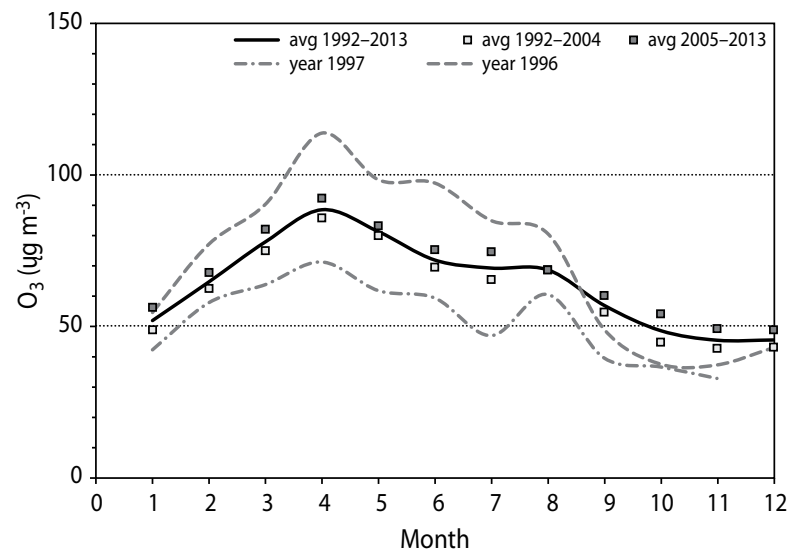

Figure 6. Monthly $\mathrm{O}_{3}$ means $\left[\mathrm{\mu g} \mathrm{m}^{-3}\right]$ averaged for different periods: long-term 1992-2013; before and after windstorm 2004; year 1996 related to $\mathrm{O}_{3}$ annual maximum, and year 1997 related to $\mathrm{O}_{3}$ annual minimum

$\mathrm{O}_{3}$ concentrations start to decrease during autumn and continue to winter minima $\left(45 \mu \mathrm{g} \mathrm{m}^{-3}\right.$ in November-December). From January to March $\mathrm{O}_{3}$ concentrations gradually rise until reaching primary spring maximum. Monthly means averaged over period after windstorm (avg 2005-2013) are slightly above long-term line and suggest moderate $\mathrm{O}_{3}$ increase in comparison with a period before windstorm (avg 1992-2001). Up- 


\section{DE GRUYTER

per spring level (above $100 \mu \mathrm{g} \mathrm{m}^{-3}$ ) of noticed monthly $\mathrm{O}_{3}$ averages is illustrated by 1996 line with the highest $\mathrm{O}_{3}$ annual mean. On the other hand, monthly $\mathrm{O}_{3}$ means under $75 \mu \mathrm{g} \mathrm{m}^{-3}$ (1997) characterize seasons with weak $\mathrm{O}_{3}$ production at Stará Lesná site.

\section{Daily course of $\mathrm{O}_{3}$ concentration}

Daily course of hourly $\mathrm{O}_{3}$ concentration (fig. 7) averaged for the long time period 1992-2013 is characterized by the minimum $\left(51 \mu \mathrm{g} \mathrm{m}^{-3}\right)$ in early morning hours (4-5 h UTC, 5-6 h local time). The concentration is rising steadily while reaching its peak $81 \mu \mathrm{g} \mathrm{m}^{-3}$ in the afternoon (14 h UTC) and then gradually starts to decrease. Later on it shows the sequence of low night and morning $\mathrm{O}_{3}$ values. Similar results were presented by Kremler (2002). Daily course after windstorm (avg 2005-2013) shows moderately higher values in comparison with long-term average, especially for night hours.

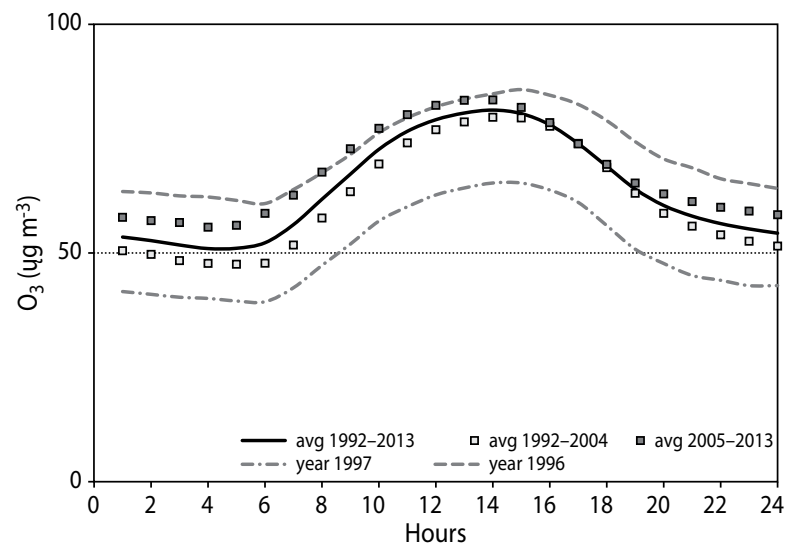

Figure 7. Hourly $\mathrm{O}_{3}$ means $\left[\mu \mathrm{g} \mathrm{m}^{-3}\right]$ averaged for different periods: long-term 1992-2013; before and after windstorm 2004; year 1996 related to annual maximum, and year 1997 related to $\mathrm{O}_{3}$ annual minimum

\section{Changes of $\mathrm{O}_{3}$ after windstorm in 2004}

Changes of $\mathrm{O}_{3}$ were investigated using hourly $\mathrm{O}_{3}$ data averaged over the period before $\left(\mathrm{O}_{3 \_}\right.$avg92-04) and after $\left(\mathrm{O}_{3}\right.$ avg05-13) windstorm in 2004. The Kriging interpolation (Surfer software) of differences between $\mathrm{O}_{3 \_}$avg92-04 and $\mathrm{O}_{3 \_}$avg05-13 shows changes in $\mathrm{O}_{3}$ production, especially for night (increase) and daylight (decrease) hours (fig. 8). Larger increase (more than $30 \%$ ) was identified for night and early morning hours (0-6h) from April to May after 2004. Moreover, approximately $10-20 \%$ increase for late autumn and winter seasons (Oct-Feb) was also noticed. On the other hand, decrease down to $-15 \%$ in spring and summer seasons indicate lower photochemical $\mathrm{O}_{3}$ production during daylight hours.

Statistical analysis (Statgraphics software) indicates significant relations between $\mathrm{O}_{3}$ concentrations before and after windstorm for two selected time periods: (1) from April to May in hourly interval from 0 to 6 hours; (2) for July in hourly interval from 12 to 20 hours. The output (tab. 2) shows the results of fitting a linear model to describe the relationship between $\mathrm{O}_{3 \_}$avg92-04 and $\mathrm{O}_{3 \_}$avg05-13. Since the P-value in the ANOVA table is less than 0.05 , there is a statistically significant relationship between $\mathrm{O}_{3}$ avg92-04 and $\mathrm{O}_{3 \_}$avg 05-13 at the $95.0 \%$ confidence level for both periods.

The R-Squared statistic indicates that the model as fitted explains $56.5716 \%$ and $90.1283 \%$ of the variability in the first case (1) and second one (2), respectively. The correlation coefficient equals 0.752141 indicating a moderately strong relationship between the variables for selected spring period and relatively strong relationship between the variables covering part of summer period. The standard error of the estimate shows the standard deviation of the residuals to be 3.47302 (1) and 2.8436 (2). These values can be used to construct prediction limits for new observations by selecting the Forecasts option from the text menu. Figure 9 includes plots of fitted models (left) and comparison of $\mathrm{O}_{3}$ courses for considering periods (right) that illustrate significant changes of $\mathrm{O}_{3}$ found after windstorm in 2004 .

The troposphere is the oxidizing environment where oxidant agents such as $\mathrm{O}_{3}$, hydroxyl radical $\left(\mathrm{HO}_{\mathrm{x}}\right)$ and hydrogen peroxide $\left(\mathrm{HO}_{2}\right)$ remove several air pollutants $\left(\mathrm{NO}, \mathrm{CO}, \mathrm{CH}_{4}\right.$ ). Key role in $\mathrm{O}_{3}$ formation plays nitrogen oxides $\left(\mathrm{NO}_{\mathrm{x}}=\mathrm{NO}+\mathrm{NO}_{2}\right)$. The mere presence of $\mathrm{NO}_{\mathrm{x}}$ does not lead to an increase in $\mathrm{O}_{3}$ concentrations. Reaction scheme of $\mathrm{O}_{3}$ formation includes cyclic sequence $(1-4)$ resulted in zero $\mathrm{O}_{3}$ production balance.

\begin{tabular}{|c|c|c|c|c|}
\hline $\mathrm{NO}+\mathrm{O}_{3}$ & $\rightarrow$ & $\mathrm{NO}_{2}+\mathrm{O}_{2}$ & $\mathrm{O}_{3}$ depletion & $(1)$ \\
\hline $\mathrm{NO}_{2}+\mathrm{h} v$ & $\rightarrow$ & $\mathrm{NO}+\mathrm{O}$ & NO regeneration & $(2)$ \\
\hline $\mathrm{O}+\mathrm{O}_{2}$ & $\rightarrow$ & $\mathrm{O}_{3}$ & $\mathrm{O}_{3}$ production & $(3)$ \\
\hline $\mathrm{O}_{3}+\mathrm{O}_{2}$ & $\rightarrow$ & $\mathrm{O}_{2}+\mathrm{O}_{3}$ & Zero $\mathrm{O}_{3}$ balance & $(4)$ \\
\hline
\end{tabular}




\section{DE GRUYTER OPEN}

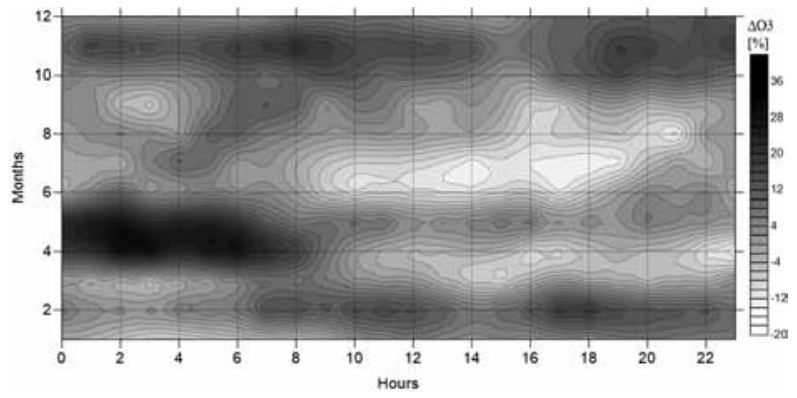

Figure 8. Temporal distribution of differences [\%] between hourly $\mathrm{O}_{3}$ concentrations $\left[\mu \mathrm{g} \mathrm{m}^{-3}\right]$ averaged for periods before (1992-2004) and after (2005-2013) windstorm
The accumulation of $\mathrm{O}_{3}$ occurs in a polluted environment where the oxidation of $\mathrm{NO}$ to $\mathrm{NO}_{2}$ mediates particularly oxidizing radicals through reactions (5-9).

VOC both from anthropogenic and biogenic sources produce various types of oxygenated hydrocarbons (carbonyl) and the other radicals via ozonolysis mechanism (10-12) where $\mathrm{O}_{3}$ is consumed during daylight and night hours alike.

The mechanism of the reaction of ozone with olefins is carried out in several steps (10), which run through the formation of the unstable primary ozonide

Table 2. Statistical characteristics of simple regression relation between $\mathrm{O}_{3}$ concentrations before and after windstorm for two selected time period

Simple Regression: Linear model: $\mathrm{Y}=\mathrm{a}+\mathrm{b} * \mathrm{X}$

\begin{tabular}{|c|c|c|c|c|c|}
\hline & Dependent & $\begin{array}{l}\text { aple Regres } \\
: \mathrm{Y}=\mathrm{O}_{3 \_} \mathrm{av}\end{array}$ & $\begin{array}{l}\text { ear model: } \mathrm{Y}= \\
\text { ndependent va }\end{array}$ & $\mathrm{O}_{3}$ avg9 & \\
\hline & & $\begin{array}{r}\text { Correlat } \\
\text { R-squ } \\
\text { Standa }\end{array}$ & $\begin{array}{l}\text { y- } 6 \mathrm{~h} \\
+0.67 * \mathrm{X} \\
\text { cient }=\mathbf{0 . 7 5 2 1} \\
\mathbf{. 5 7 1 6} \text { per cent } \\
\text { f Est. }=\mathbf{3 . 4 7 3 0}\end{array}$ & & \\
\hline Coefficients & Least Squares & Standard & $\mathrm{T}$ & & \\
\hline Parameter & Estimate & Error & Statistic & P-Value & \\
\hline Intercept & 45.3636 & 10.4945 & 4.32263 & 0.0010 & \\
\hline Slope & 0.668603 & 0.169109 & 3.95369 & 0.0019 & \\
\hline & & & f Variance & & \\
\hline Source & Sum of Squares & Df & Mean Square & F-Ratio & P-Value \\
\hline Model & 188.547 & 1 & 188.547 & 15.63 & 0.0019 \\
\hline Residual & 144.742 & 12 & 12.0619 & & \\
\hline Total (Corr.) & 333.289 & 13 & & & \\
\hline & & $\begin{array}{r}\text { Correlat } \\
\text { R-squ } \\
\text { Standa }\end{array}$ & $\begin{array}{l}-20 \mathrm{~h} \\
+0.85^{*} \mathrm{X} \\
\text { cient }=\mathbf{0 . 9 4 9 3} \\
\mathbf{1 2 8 3} \text { per cent } \\
\text { f Est. }=\mathbf{2 . 8 4 3}\end{array}$ & & \\
\hline Coefficients & Least Squares & Standard & $\mathrm{T}$ & & \\
\hline Parameter & Estimate & Error & Statistic & P-Value & \\
\hline Intercept & 2.91897 & 9.8198 & 0.297253 & 0.7749 & \\
\hline Slope & 0.846143 & 0.105842 & 7.99437 & 0.0001 & \\
\hline & & & f Variance & & \\
\hline Source & Sum of Squares & Df & Mean Square & F-Ratio & P-Value \\
\hline Model & 516.78 & 1 & 516.78 & 63.91 & 0.0001 \\
\hline Residual & 56.6024 & 7 & 8.08605 & & \\
\hline Total (Corr.) & 573.382 & 8 & & & \\
\hline
\end{tabular}



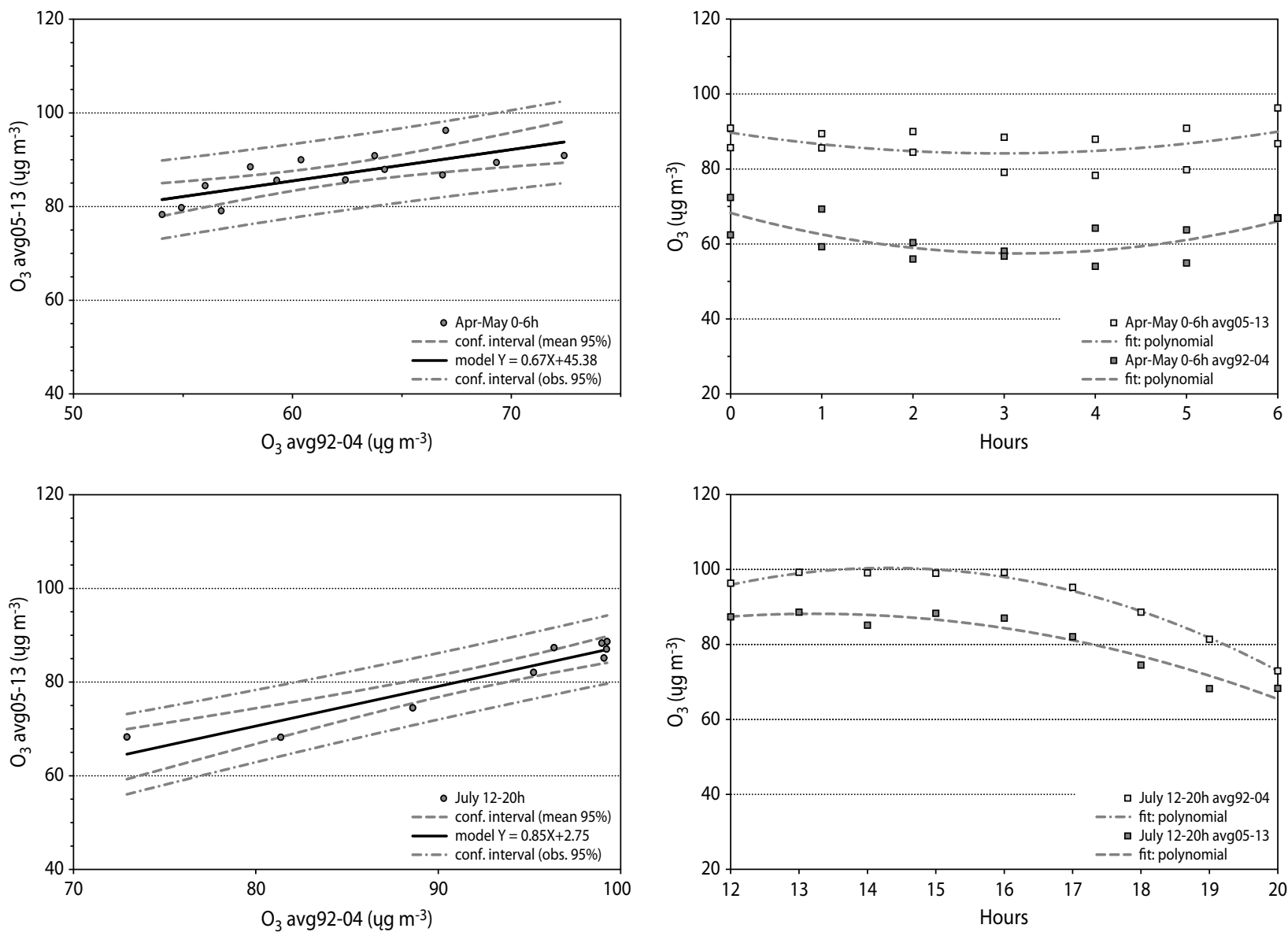

Figure 9. Simple regression relationship between $\mathrm{O}_{3}$ concentrations (left) and comparison of $\mathrm{O}_{3}$ course (right) for two considering periods related to significant changes of $\mathrm{O}_{3}$ after windstorm in 2004

(POZ) to give Criegee intermediate (CI) and group of carbonyl compounds $(\mathrm{CC})$ :

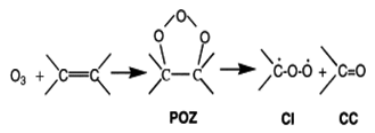

Reactive $\mathrm{OH}$ and $\mathrm{HO}_{2}$ radicals occur via the formation of a vibrationally excited unsaturated hydroperoxide (11-12) during the ozonolysis of 2-butene (Niki et al. 1987).

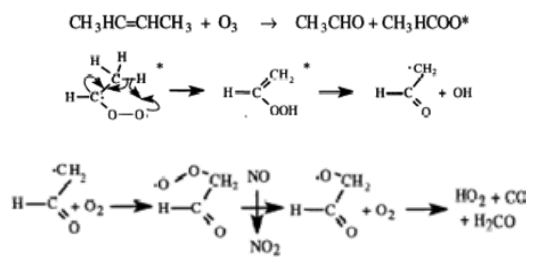

Although the general mechanism of the reaction of $\mathrm{O}_{3}$ with long chain alkenes chain (1-butene, trans-2-butene, 2-methylpropene, a-pinén, 2,3-dimethyl-2butén, isoprene) is not completely clear, higher production of $\mathrm{OH}$ radicals is estimated in comparison with the short chain alkenes (Paulson and Orlando 1996).

Reaction mechanisms presented above describe key processes of formation and depletion of $\mathrm{O}_{3}$ in the troposphere. Natural volatile organic compounds emitted from forest vegetation play a considerable role in these processes. Since $\mathrm{O}_{3}$ is formed from the photochemical oxidation of $\mathrm{VOC}_{\mathrm{s}}$ in the presence of $\mathrm{NO}_{\mathrm{x}}$, the inclusion of BVOC emissions enhances its formation, especially in VOC-limited regions. Daily average maximum $8 \mathrm{~h}$ ozone $\left(\mathrm{Max} 8 \mathrm{hrO}_{3}\right)$ mixing ratio due to the inclusion of BVOC emissions is up to $23 \%$ higher (Tagaris et al. 2014). BVOC consumption undergoes chemical 


\section{DE GRUYTER OPEN}

oxidation through ozonolysis is important with respect of $\mathrm{HO}_{\mathrm{X}}\left(\mathrm{OH}\right.$ and $\left.\mathrm{HO}_{2}\right)$ and $\mathrm{RO}_{2}$ radicals in remote areas and for secondary organic aerosol (SOA) formation (Ziemann and Atkinson 2012). Myrcene is one of the major monoterpenes in the emissions from coniferous forests. The results of chamber experiments indicate the formation of hydroxyacetone as a direct product of the myrcene reaction with $\mathrm{O}_{3}$ with a molar yield of $17.6 \%$ (Böge et al. 2013). Evaluation of $\mathrm{O}_{3}$ measurements at Stará Lesná shows association between BVOC decrease and changes of $\mathrm{O}_{3}$ concentration after windstorm in 2004. We can assume that reduced BVOC sources resulted in the decrease of $\mathrm{O}_{3}$ daylight concentrations in summer due to the lower production of reactive $\mathrm{OH}$, $\mathrm{HO}_{2}$ radicals. In contrast, the deficit of BVOC may cause a significant increase of $\mathrm{O}_{3}$ night concentrations in spring due to lower $\mathrm{O}_{3}$ depletion via ozonolysis.

\section{Conclusions}

In the past decade, the High Tatras were affected by several natural disasters (strong windstorms, forest fires, flooding, insect invasions, etc.) as well as by an extensive construction of tourist centres and development of ski resorts. These events contributed to several visible landscape changes in the area including large deforestation of uphill slopes. Spacious destruction of forested area caused the reduction of natural emissions from forest vegetation that play important role in surface ozone chemistry. The analysis of long-term $\mathrm{O}_{3}$ data series for foothill station Stará Lesná suggests an association between BVOC and $\mathrm{O}_{3}$ concentrations in the context of land cover changes. Both, the decrease of daylight and increase of nightly $\mathrm{O}_{3}$ concentrations for selected period is linked to changes of BVOC after windstorm in 2004. Further research is needed to take account of climate factor and the effect of long-range transport.

\section{Acknowledgment}

This research was supported by the Grant Agency SR under projects VEGA No. 2/0053/14, No. 2/0089/14, No. 2/0027/13, No. 2/0089/14 and by the Slovak Research and Development Agency under the contract No. APVV-
0429-12. The authors are grateful to the Slovak Hydrometeorological Institute for providing the EMEP data.

\section{References}

Bičárová S., Fleischer P. 2004. Ground level ozone at the meteorological observatory Stará Lesná. Contributions to Geophysics and Geodesy, 34 (2), 111-129.

Bičárová S., Fleischer P. 2006. Windstorm effect on forest sources of biogenic volatile organic compound emissions in the High Tatras. Contributions to Geophysics and Geodesy, 36 (3), 269-282.

Bičárová S., Pavlendová H., Fleischer P. 2013. Vulnerability to ozone air pollution in different landforms of Europe. In: Air pollution: sources, prevention and health effects (ed.: R. Sethi), Nova Science Publishers, New York, 25-63.

Bičárová S., Sojáková M., Burda C., Fleischer P. 2005. Summer ground level ozone maximum in Slovakia in 2003. Contributions to Geophysics and Geodesy, 35 (3), 265-279.

Böge O., Mutzel A., Iinuma Y., Yli-Pirilä P., Kahnt A., Joutsensaari J., Herrmann H. 2013. Gas-phase products and secondary organic aerosol formation from the ozonolysis and photooxidation of myrcene. Atmospheric Environment, 79, 553-560.

Chameides W.L., Fehsenfeld F., Rodgers M.O., Cardelino C., Martinez J., Parrish D., Lonneman W., Lawson D.R., Rasmussen R.A., Zimmerman P., Greenberg J., Middleton P., Wang T. 1992. Ozone precursor relationships in the ambient atmosphere. Journal of Geophysical Research, 97, 6037-6055.

Fiala J., Cernikovsky L., de Leeuw F., Kurfuerst P. 2003. Air pollution ozone in Europe in summer 2003. EEA Topic Report No. 3, EEA, Copenhagen.

Fleischer P. 2011. Pokalamitný výskum vo Vysokých Tatrách - ciele, metóda a charakteristika lokalít. In: Štúdie o Tatranskom národnom parku = Studies on Tatra National Park (eds.: P. Fleischer, Z. Homolová), ŠL TANAP, Poprad, 7-12.

Fowler D. 2008. Ground-level ozone in the 21st century: future trends, impacts and policy implications. Science Policy, 15, 1-132.

Guenther A., Zimmerman P., Harley P., Monson R., Fall R. 1993. Isoprene and monoterpene emission rate variability: Model evaluation and sensitiv- 
ity analysis. Journal of Geophysical Research, 98, 12609-12617.

Guenther A., Archer S., Harley P., Helmig D., Klinger L., Vierling L., Wildermuth M., Zimmerman P., Zitzer S. 1999a. Biogenic hydrocarbon emissions and landcover/climate change merman, in a subtropical savanna. Physics and Chemistry of the Earth, 24 (6), 659-667.

Guenther A., Baugh B., Brasseur G., Geenberg J., Harley P., Klinger L., Serca D., Vierling L. 1999b. Isoprene emission estimates and uncertainties for the Central African EXPRESSO study domain. Journal of Geophysical Research, 104, 30625-30639.

Kremler M. 2002. Daily and annual course of surface ozone concentrations at Slovak monitoring stations. Meteorological Journal, 7, 29-36.

Louka P., Finzi G., Volta M., Colbeck I. 2003. Studying atmospheric pollution in urban areas (Saturn), Final Report, (ed. Moussiopoulos). Springer Verlag, Germany.

Niki H., Maker P.D., Savage C.M., Breitenbach L.P. 1987. FTIR Spectroscopic study of the mechanism for the gas-phase reaction between ozone and tetramethylene. Journal of American Chemical Society, 91, 941-946.
Paulson S.E., Orlando J.J. 1996. The reactions of ozone with alkenes: an important source of $\mathrm{HO}_{\mathrm{x}}$ in the boundary layer. Geophysical Research Letters, 23, 3727-3730.

Stocker T.F. 2013. Summary for Policymakers, Technical Summary and frequently asked questions, Working Group I - the Physical Science Basis contribution to the fifth assessment report of the Intergovernmental Panel, IPCC.

Škvarenina J., Fleischer P. 2013. Bioclimatological condition and vegetation. In: Obseravatory of SAS at Skalnaté Pleso - 70 years of meteorological measurements (ed.: S. Bičárová), GFÚ SAV, Stará Lesná, 11-15.

Tagaris E., Sotiropoulou R.E.P., Gounaris N., Andronopoulos S., Vlachogiannis D. 2014. Impact of biogenic emissions on ozone and fine particles over Europe: comparing effects of temperature increase and a potential anthropogenic $\mathrm{NO}_{\mathrm{x}}$ emissions abatement strategy. Atmospheric Environment, 98, 214-223.

Ziemann P.J., Atkinson R. 2012 Kinetics, products, and mechanisms of secondary organic aerosol formation. Chemical Society Reviews, 41, 6582-6605. 